\title{
Coronavirus (CoV) proteins in GtoPdb v.2021.3
}

\author{
Stephen P.H. Alexander ${ }^{1}$, Jonathan K. Ball ${ }^{1}$ and Theocharis Tsoleridis ${ }^{1}$
}

1. University of Nottingham, UK

\begin{abstract}
Coronaviruses are large, often spherical, enveloped, single-stranded positive-sense RNA viruses, ranging in size from $80-220 \mathrm{~nm}$. Their genomes and protein structures are highly conserved. Three coronaviruses have emerged over the last 20 years as serious human pathogens: SARS-CoV was identified as the causative agent in an outbreak in 2002-2003, Middle East respiratory syndrome (MERS) CoV emerged in 2012 and the novel coronavirus SARS-CoV-2 emerged in 2019-2020. SARSCoV-2 is the virus responsible for the infectious disease termed COVID-19 (WHO Technical Guidance 2020).
\end{abstract}

\section{Contents}

This is a citation summary for Coronavirus (CoV) proteins in the Guide to Pharmacology database (GtoPdb). It exists purely as an adjunct to the database to facilitate the recognition of citations to and from the database by citation analyzers. Readers will almost certainly want to visit the relevant sections of the database which are given here under database links.

GtoPdb is an expert-driven guide to pharmacological targets and the substances that act on them. GtoPdb is a reference work which is most usefully represented as an on-line database. As in any publication this work should be appropriately cited, and the papers it cites should also be recognized. This document provides a citation for the relevant parts of the database, and also provides a reference list for the research cited by those parts. For further details see [13].

Please note that the database version for the citations given in GtoPdb are to the most recent preceding version in which the family or its subfamilies and targets were substantially changed. The links below are to the current version. If you need to consult the cited version, rather than the most recent version, please contact the GtoPdb curators.

\section{Database links}

Coronavirus $(\mathrm{CoV})$ proteins

https://www.guidetopharmacology.org/GRAC/FamilyDisplayForward?familyId=1034

Introduction to Coronavirus (CoV) proteins

https://www.guidetopharmacology.org/GRAC/FamilyIntroductionForward?familyId=1034

Targets

CoV Envelope protein

https://www.guidetopharmacology.org/GRAC/ObjectDisplayForward?objectId=3116

CoV 3C-like (main) protease

https://www.guidetopharmacology.org/GRAC/ObjectDisplayForward?objectId=3111

CoV Membrane glycoprotein

https://www.guidetopharmacology.org/GRAC/ObjectDisplayForward?objectId=3117

CoV Non-structural protein 6

https://www.guidetopharmacology.org/GRAC/ObjectDisplayForward?objectId=3118

CoV Non-structural protein $7 \mathrm{~b}$

https://www.guidetopharmacology.org/GRAC/ObjectDisplayForward?objectId=3123

CoV Non-structural protein 8

https://www.guidetopharmacology.org/GRAC/ObjectDisplayForward?objectId=3120

CoV Nucleoprotein

https://www.guidetopharmacology.org/GRAC/ObjectDisplayForward?objectId=3121

CoV Papain-like protease 
https://www.guidetopharmacology.org/GRAC/ObjectDisplayForward?objectId=3132 CoV Protein 3a

https://www.guidetopharmacology.org/GRAC/ObjectDisplayForward?objectId=3115 CoV Protein 7a

https://www.guidetopharmacology.org/GRAC/ObjectDisplayForward?objectId=3119 CoV Protein 9b

https://www.guidetopharmacology.org/GRAC/ObjectDisplayForward?objectId=3122 CoV Replicase polyprotein $1 \mathrm{a}$

https://www.guidetopharmacology.org/GRAC/ObjectDisplayForward?objectId=3124 CoV Replicase polyprotein $1 \mathrm{ab}$

https://www.guidetopharmacology.org/GRAC/ObjectDisplayForward?objectId=3125 CoV RNA-dependent RNA polymerase

https://www.guidetopharmacology.org/GRAC/ObjectDisplayForward?objectId=3139 CoV Spike glycoprotein

https://www.guidetopharmacology.org/GRAC/ObjectDisplayForward?objectId=3114

\section{References}

1. Adedeji AO, Marchand B, Te Velthuis AJ, Snijder EJ, Weiss S, Eoff RL, Singh K and Sarafianos SG. (2012) Mechanism of nucleic acid unwinding by SARS-CoV helicase. PLoS ONE 7: e36521 [PMID:22615777]

2. Ahn DG, Choi JK, Taylor DR and Oh JW. (2012) Biochemical characterization of a recombinant SARS coronavirus nsp12 RNA-dependent RNA polymerase capable of copying viral RNA templates. Arch Virol 157: 2095-104 [PMID:22791111]

3. Angelini MM, Akhlaghpour M, Neuman BW and Buchmeier MJ. (2013) Severe acute respiratory syndrome coronavirus nonstructural proteins 3, 4, and 6 induce double-membrane vesicles. mBio 4 [PMID:23943763]

4. Anson BJ, Chapman ME, Lendy EK, Pshenychnyi S, D'Aquila RT, Satchell KJF and Mesecar AD. (2020) Broad-spectrum inhibition of coronavirus main and papain-like proteases by HCV drugs Nature Research

5. Bafna K, White K, Harish B, Rosales R, Ramelot TA, Acton TB, Moreno E, Kehrer T, Miorin L and Royer CA et al.. (2021) Hepatitis C virus drugs that inhibit SARS-CoV-2 papain-like protease synergize with remdesivir to suppress viral replication in cell culture. Cell Rep: 109133 [PMID:33984267]

6. Bai B, Belovodskiy A, Hena M, Kandadai AS, Joyce MA, Saffran HA, Shields JA, Khan MB, Arutyunova E and Lu J et al.. (2021) Peptidomimetic $\alpha$-Acyloxymethylketone Warheads with SixMembered Lactam P1 Glutamine Mimic: SARS-CoV-2 3CL Protease Inhibition, Coronavirus Antiviral Activity, and in Vitro Biological Stability. J Med Chem [PMID:34242027]

7. Baker JD, Uhrich RL, Kraemer GC, Love JE and Kraemer BC. (2021) A drug repurposing screen identifies hepatitis $C$ antivirals as inhibitors of the SARS-CoV2 main protease. PLoS One 16: e0245962 [PMID:33524017]

8. Barretto N, Jukneliene D, Ratia K, Chen Z, Mesecar AD and Baker SC. (2005) The papain-like protease of severe acute respiratory syndrome coronavirus has deubiquitinating activity. $J$ Virol 79: 15189-98 [PMID:16306590]

9. Botyanszki J, Catalano G, Chong PY, Dickson H, Jin Q, Leivers A, Maynard A, Liao X, Miller J and Shotwell JB et al.. (2018) Compounds that inhibit 3c and 3cl proteases and methods of use thereof Patent number: WO2018042343A2.

10. Bouvet M, Debarnot C, Imbert I, Selisko B, Snijder EJ, Canard B and Decroly E. (2010) In vitro reconstitution of SARS-coronavirus mRNA cap methylation. PLoS Pathog 6: e1000863 [PMID:20421945]

11. Bouvet M, Imbert I, Subissi L, Gluais L, Canard B and Decroly E. (2012) RNA 3'-end mismatch excision by the severe acute respiratory syndrome coronavirus nonstructural protein nsp10/nsp14 exoribonuclease complex. Proc Natl Acad Sci USA 109: 9372-7 [PMID:22635272]

12. Breidenbach J, Lemke C, Pillaiyar T, Schäkel L, Al Hamwi G, Diett M, Gedschold R, Geiger N, Lopez V and Mirza S et al.. (2021) Targeting the Main Protease of SARS-CoV-2: From the Establishment of High Throughput Screening to the Design of Tailored Inhibitors. Angew Chem Int Ed Engl [PMID:33655614]

13. Buneman P, Christie G, Davies JA, Dimitrellou R, Harding SD, Pawson AJ, Sharman JL and Wu Y. (2020) Why data citation isn't working, and what to do about it Database 2020 [PMID:32367113]

14. Báez-Santos YM, Barraza SJ, Wilson MW, Agius MP, Mielech AM, Davis NM, Baker SC, Larsen SD and Mesecar AD. (2014) X-ray structural and biological evaluation of a series of potent and highly selective inhibitors of human coronavirus papain-like proteases. J Med Chem 57: 2393412 [PMID:24568342]

15. Cao L, Goreshnik I, Coventry B, Case JB, Miller L, Kozodoy L, Chen RE, Carter L, Walls AC and Park YJ et al.. (2020) De novo design of picomolar SARS-CoV-2 miniprotein inhibitors. Science 
370: 426-431 [PMID:32907861]

16. Chamakuri S, Lu S, Ucisik MN, Bohren KM, Chen YC, Du HC, Faver JC, Jimmidi R, Li F and Li JY et al.. (2021) DNA-encoded chemistry technology yields expedient access to SARS-CoV-2 Mpro inhibitors. Proc Natl Acad Sci U S A 118 [PMID:34426525]

17. Chen IY, Moriyama M, Chang MF and Ichinohe T. (2019) Severe Acute Respiratory Syndrome Coronavirus Viroporin 3a Activates the NLRP3 Inflammasome. Front Microbiol 10: 50 [PMID:30761102]

18. Cheng Y-W, Chao T-L, Li C-L, Chen P-J, Chang S-Y and Yeh S-H. (2020) Furin Inhibitors Block SARS-CoV-2 Spike Protein Cleavage to Suppress Virus Production and Cytopathic Effects Cell Reports

19. Chi Y, Yan R, Zhang J, Zhang G, Zhang Y, Hao M, Zhang Z, Fan P, Dong Y and Yang Y et al.. (2020) A neutralizing human antibody binds to the N-terminal domain of the Spike protein of SARS-CoV-2 Science

20. Chinese SARS Molecular Epidemiology Consortium. (2004) Molecular evolution of the SARS coronavirus during the course of the SARS epidemic in China. Science 303: 1666-9 [PMID:14752165]

21. Chuck CP, Chen C, Ke Z, Wan DC, Chow HF and Wong KB. (2013) Design, synthesis and crystallographic analysis of nitrile-based broad-spectrum peptidomimetic inhibitors for coronavirus 3C-like proteases. Eur J Med Chem 59: 1-6 [PMID:23202846]

22. Cornillez-Ty CT, Liao L, Yates 3rd JR, Kuhn P and Buchmeier MJ. (2009) Severe acute respiratory syndrome coronavirus nonstructural protein 2 interacts with a host protein complex involved in mitochondrial biogenesis and intracellular signaling. J Virol 83: 10314-8 [PMID:19640993]

23. Cottam EM, Whelband MC and Wileman T. (2014) Coronavirus NSP6 restricts autophagosome expansion. Autophagy 10: 1426-41 [PMID:24991833]

24. Dai W, Jochmans D, Xie H, Yang H, Li J, Su H, Chang D, Wang J, Peng J and Zhu L et al.. (2021) Design, Synthesis, and Biological Evaluation of Peptidomimetic Aldehydes as Broad-Spectrum Inhibitors against Enterovirus and SARS-CoV-2. J Med Chem [PMID:33872498]

25. Dai W, Zhang B, Jiang XM, Su H, Li J, Zhao Y, Xie X, Jin Z, Peng J and Liu F et al.. (2020) Structure-based design of antiviral drug candidates targeting the SARS-CoV-2 main protease. Science 368: 1331-1335 [PMID:32321856]

26. Dampalla CS, Kim Y, Bickmeier N, Rathnayake AD, Nguyen HN, Zheng J, Kashipathy MM, Baird MA, Battaile KP and Lovell S et al.. (2021) Structure-Guided Design of Conformationally Constrained Cyclohexane Inhibitors of Severe Acute Respiratory Syndrome Coronavirus-2 3CL Protease. J Med Chem [PMID:34213885]

27. de Vries RD, Schmitz KS, Bovier FT, Noack D, Haagmans BL, Biswas S, Rockx B, Gellman SH, Alabi CA and de Swart RL et al.. (2020) Intranasal fusion inhibitory lipopeptide prevents direct contact SARS-CoV-2 transmission in ferrets. bioRxiv [PMID:33173865]

28. Devaraj SG, Wang N, Chen Z, Chen Z, Tseng M, Barretto N, Lin R, Peters CJ, Tseng CT and Baker SC et al.. (2007) Regulation of IRF-3-dependent innate immunity by the papain-like protease domain of the severe acute respiratory syndrome coronavirus. J Biol Chem 282: 3220821 [PMID:17761676]

29. Dong S, Sun J, Mao Z, Wang L, Lu YL and Li J. (2020) A guideline for homology modeling of the proteins from newly discovered betacoronavirus, 2019 novel coronavirus (2019-nCoV). J Med Virol 92: 1542-1548 [PMID:32181901]

30. Drayman R, DeMarco JK, Jones KA, Azizi S-A, Froggatt HM, Tan K, Maltseva NI, Chen S, Nicolaescu V and Dvorkin S et al.. (2021) Masitinib is a broad coronavirus 3CL inhibitor that blocks replication of SARS-CoV-2 Science

31. Fan H, Ooi A, Tan YW, Wang S, Fang S, Liu DX and Lescar J. (2005) The nucleocapsid protein of coronavirus infectious bronchitis virus: crystal structure of its N-terminal domain and multimerization properties. Structure 13: 1859-68 [PMID:16338414]

32. Freitas BT, Durie IA, Murray J, Longo JE, Miller HC, Crich D, Hogan RJ, Tripp RA and Pegan SD. (2020) Characterization and Noncovalent Inhibition of the Deubiquitinase and deISGylase Activity of SARS-CoV-2 Papain-Like Protease. ACS Infect Dis 6: 2099-2109 [PMID:32428392]

33. Fung TS and Liu DX. (2019) Human Coronavirus: Host-Pathogen Interaction. Annu Rev Microbiol 73: 529-557 [PMID:31226023]

34. Ghosh AK, Gong G, Grum-Tokars V, Mulhearn DC, Baker SC, Coughlin M, Prabhakar BS, Sleeman K, Johnson ME and Mesecar AD. (2008) Design, synthesis and antiviral efficacy of a series of potent chloropyridyl ester-derived SARS-CoV 3CLpro inhibitors. Bioorg Med Chem Lett 18: 5684-8 [PMID:18796354]

35. Gong YN, Tsao KC, Hsiao MJ, Huang CG, Huang PN, Huang PW, Lee KM, Liu YC, Yang SL and Kuo RL et al.. (2020) SARS-CoV-2 genomic surveillance in Taiwan revealed novel ORF8-deletion mutant and clade possibly associated with infections in Middle East. Emerg Microbes Infect 9: 1457-1466 [PMID:32543353]

36. Gordon CJ, Tchesnokov EP, Woolner E, Perry JK, Feng JY, Porter DP and Götte M. (2020) Remdesivir is a direct-acting antiviral that inhibits RNA-dependent RNA polymerase from severe 
acute respiratory syndrome coronavirus 2 with high potency. J Biol Chem 295: 6785-6797 [PMID:32284326]

37. Gordon DE, Jang GM, Bouhaddou M, Xu J, Obernier K, White KM, O'Meara MJ, Rezelj VV, Guo JZ and Swaney DL et al.. (2020) A SARS-CoV-2 protein interaction map reveals targets for drug repurposing. Nature 583: 459-468 [PMID:32353859]

38. Han SH, Goins CM, Arya T, Shin WJ, Maw J, Hooper A, Sonawane DP, Porter MR, Bannister BE and Crouch RD et al.. (2021) Structure-Based Optimization of ML300-Derived, Noncovalent Inhibitors Targeting the Severe Acute Respiratory Syndrome Coronavirus 3CL Protease (SARSCoV-2 3CL ${ }^{\text {pro }) . ~ J ~ M e d ~ C h e m ~[P M I D: 34347470] ~}$

39. Hansen J, Baum A, Pascal KE, Russo V, Giordano S, Wloga E, Fulton BO, Yan Y, Koon K and Patel K et al.. (2020) Studies in humanized mice and convalescent humans yield a SARS-CoV-2 antibody cocktail. Science 369: 1010-1014 [PMID:32540901]

40. Harcourt BH, Jukneliene D, Kanjanahaluethai A, Bechill J, Severson KM, Smith CM, Rota PA and Baker SC. (2004) Identification of severe acute respiratory syndrome coronavirus replicase products and characterization of papain-like protease activity. J Virol 78: 13600-12 [PMID:15564471]

41. Hattori SI, Higashi-Kuwata N, Hayashi H, Allu SR, Raghavaiah J, Bulut H, Das D, Anson BJ, Lendy EK and Takamatsu Y et al.. (2021) A small molecule compound with an indole moiety inhibits the main protease of SARS-CoV-2 and blocks virus replication. Nat Commun 12: 668 [PMID:33510133]

42. He WT, Wan H, Hu L, Chen P, Wang X, Huang Z, Yang ZH, Zhong CQ and Han J. (2015)

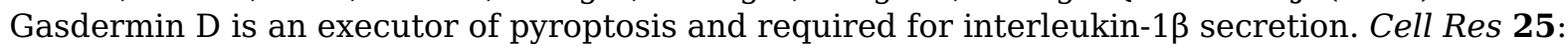
1285-98 [PMID:26611636]

43. Hilgenfeld R. (2014) From SARS to MERS: crystallographic studies on coronaviral proteases enable antiviral drug design. FEBS J 281: 4085-96 [PMID:25039866]

44. Hoffman RL, Kania RS, Brothers MA, Davies JF, Ferre RA, Gajiwala KS, He M, Hogan RJ, Kozminski K and Li LY et al.. (2020) Discovery of Ketone-Based Covalent Inhibitors of Coronavirus 3CL Proteases for the Potential Therapeutic Treatment of COVID-19. J Med Chem 63: 12725-12747 [PMID:33054210]

45. Hoffmann M, Arora P, Groß R, Seidel A, Hörnich BF, Hahn AS, Krüger N, Graichen L, HofmannWinkler $\mathrm{H}$ and Kempf A et al.. (2021) SARS-CoV-2 variants B.1.351 and P.1 escape from neutralizing antibodies Cell

46. Hoffmann M, Kleine-Weber H, Schroeder S, Krüger N, Herrler T, Erichsen S, Schiergens TS, Herrler G, Wu NH and Nitsche A et al.. (2020) SARS-CoV-2 Cell Entry Depends on ACE2 and TMPRSS2 and Is Blocked by a Clinically Proven Protease Inhibitor. Cell 181: 271-280.e8 [PMID:32142651]

47. Huo J, Zhao Y, Ren J, Zhou D, Duyvesteyn HME, Ginn HM, Carrique L, Malinauskas T, Ruza RR and Shah PNM et al.. (2020) Neutralisation of SARS-CoV-2 by destruction of the prefusion Spike. Cell Host and Microbe

48. Imbert I, Guillemot JC, Bourhis JM, Bussetta C, Coutard B, Egloff MP, Ferron F, Gorbalenya AE and Canard B. (2006) A second, non-canonical RNA-dependent RNA polymerase in SARS coronavirus. EMBO J 25: 4933-42 [PMID:17024178]

49. Jin Z, Du X, Xu Y, Deng Y, Liu M, Zhang B, Li X, Zhang L, Peng C and Duan Y. (2020) Structure of Mpro from COVID-19 virus and discovery of its inhibitors bioRxiv

50. Kim C, Ryu DK, Lee J, Kim YI, Seo JM, Kim YG, Jeong JH, Kim M, Kim JI and Kim P et al.. (2021) A therapeutic neutralizing antibody targeting receptor binding domain of SARS-CoV-2 spike protein. Nat Commun 12: 288 [PMID:33436577]

51. Kim SS, Sze L, Liu C and Lam KP. (2019) The stress granule protein G3BP1 binds viral dsRNA and RIG-I to enhance interferon- $\beta$ response. J Biol Chem 294: 6430-6438 [PMID:30804210]

52. Kim SY, Jin W, Sood A, Montgomery DW, Grant OC, Fuster MM, Fu L, Dordick JS, Woods RJ and Zhang F et al.. (2020) Characterization of heparin and severe acute respiratory syndromerelated coronavirus 2 (SARS-CoV-2) spike glycoprotein binding interactions. Antiviral Res 181: 104873 [PMID:32653452]

53. Kim Y, Jedrzejczak R, Maltseva NI, Wilamowski M, Endres M, Godzik A, Michalska K and Joachimiak A. (2020) Crystal structure of Nsp15 endoribonuclease NendoU from SARS-CoV-2. Protein Sci 29: 1596-1605 [PMID:32304108]

54. Kirchdoerfer RN and Ward AB. (2019) Structure of the SARS-CoV nsp12 polymerase bound to nsp7 and nsp8 co-factors. Nat Commun 10: 2342 [PMID:31138817]

55. Konno S, Kobayashi K, Senda M, Funai Y, Seki Y, Tamai A, Schakel L, Sakata K, Pillaiyar T and Taguchi A et al.. (2021) 3CL Protease Inhibitors with an Electrophilic Arylketone Moiety as AntiSARS-CoV-2 Agents Journal of Medicinal Chemistry [PMID:34313428]

56. Konno S, Thanigaimalai P, Yamamoto T, Nakada K, Kakiuchi R, Takayama K, Yamazaki Y, Yakushiji F, Akaji K and Kiso Y et al.. (2013) Design and synthesis of new tripeptide-type SARSCoV 3CL protease inhibitors containing an electrophilic arylketone moiety. Bioorg Med Chem 21: 412-24 [PMID:23245752] 
57. Lan J, Ge J, Yu J, Shan S, Zhou H, Fan S, Zhang Q, Shi X, Wang Q and Zhang L et al.. (2020) Structure of the SARS-CoV-2 spike receptor-binding domain bound to the ACE2 receptor. Nature 581: 215-220 [PMID:32225176]

58. Law PTW, Wong CH, Au TCC, Chuck CP, Kong SK, Chan PKS, To KF, Lo AWI, Chan JYW and Suen YK et al.. (2005) The 3a protein of severe acute respiratory syndrome-associated coronavirus induces apoptosis in Vero E6 cells. J Gen Virol 86: 1921-1930 [PMID:15958670]

59. Lee CC, Kuo CJ, Ko TP, Hsu MF, Tsui YC, Chang SC, Yang S, Chen SJ, Chen HC and Hsu MC et al.. (2009) Structural basis of inhibition specificities of 3C and 3C-like proteases by zinccoordinating and peptidomimetic compounds. J Biol Chem 284: 7646-55 [PMID:19144641]

60. Lindner HA, Lytvyn V, Qi H, Lachance P, Ziomek E and Ménard R. (2007) Selectivity in ISG15 and ubiquitin recognition by the SARS coronavirus papain-like protease. Arch Biochem Biophys 466: 8-14 [PMID:17692280]

61. Liu X, Zhang Z, Ruan J, Pan Y, Magupalli VG, Wu H and Lieberman J. (2016) Inflammasomeactivated gasdermin D causes pyroptosis by forming membrane pores. Nature 535: 153-8 [PMID:27383986]

62. Liu ZS, Cai H, Xue W, Wang M, Xia T, Li WJ, Xing JQ, Zhao M, Huang YJ and Chen S et al.. (2019) G3BP1 promotes DNA binding and activation of cGAS. Nat Immunol 20: 18-28 [PMID:30510222]

63. Lokugamage KG, Narayanan K, Huang C and Makino S. (2012) Severe acute respiratory syndrome coronavirus protein nsp1 is a novel eukaryotic translation inhibitor that represses multiple steps of translation initiation. J Virol 86: 13598-608 [PMID:23035226]

64. Lu W, Zheng BJ, Xu K, Schwarz W, Du L, Wong CK, Chen J, Duan S, Deubel V and Sun B. (2006) Severe acute respiratory syndrome-associated coronavirus 3 a protein forms an ion channel and modulates virus release. Proc Natl Acad Sci USA 103: 12540-5 [PMID:16894145]

65. Ma C, Sacco MD, Hurst B, Townsend JA, Hu Y, Szeto T, Zhang X, Tarbet B, Marty MT and Chen Y et al.. (2020) Boceprevir, GC-376, and calpain inhibitors II, XII inhibit SARS-CoV-2 viral replication by targeting the viral main protease. Cell Res 30: 678-692 [PMID:32541865]

66. Ma J, Zhu F, Zhao M, Shao F, Yu D, Ma J, Zhang X, Li W, Qian Y and Zhang Y et al.. (2021) SARS-CoV-2 nucleocapsid suppresses host pyroptosis by blocking Gasdermin D cleavage. EMBO $J:$ e108249 [PMID:34296442]

67. Miknis ZJ, Donaldson EF, Umland TC, Rimmer RA, Baric RS and Schultz LW. (2009) Severe acute respiratory syndrome coronavirus nsp9 dimerization is essential for efficient viral growth. J Virol 83: 3007-18 [PMID:19153232]

68. Minakshi R, Padhan K, Rani M, Khan N, Ahmad F and Jameel S. (2009) The SARS Coronavirus 3a protein causes endoplasmic reticulum stress and induces ligand-independent downregulation of the type 1 interferon receptor. PLoS ONE 4: e8342 [PMID:20020050]

69. Molecular Partners. Molecular Partners pipeline page

70. Muth D, Corman VM, Roth H, Binger T, Dijkman R, Gottula LT, Gloza-Rausch F, Balboni A, Battilani M and Rihtarič D et al.. (2018) Attenuation of replication by a 29 nucleotide deletion in SARS-coronavirus acquired during the early stages of human-to-human transmission. Sci Rep $\mathbf{8}$ : 15177 [PMID:30310104]

71. Nakagawa K, Narayanan K, Wada M and Makino S. (2018) Inhibition of Stress Granule Formation by Middle East Respiratory Syndrome Coronavirus 4a Accessory Protein Facilitates Viral Translation, Leading to Efficient Virus Replication. J Virol 92 [PMID:30068649]

72. Nelson CA, Pekosz A, Lee CA, Diamond MS and Fremont DH. (2005) Structure and intracellular targeting of the SARS-coronavirus Orf7a accessory protein. Structure 13: 75-85 [PMID:15642263]

73. Nieto-Torres JL, Verdiá-Báguena C, Jimenez-Guardeño JM, Regla-Nava JA, Castaño-Rodriguez C, Fernandez-Delgado R, Torres J, Aguilella VM and Enjuanes L. (2015) Severe acute respiratory syndrome coronavirus E protein transports calcium ions and activates the NLRP3 inflammasome. Virology 485: 330-9 [PMID:26331680]

74. Osipiuk J, Azizi SA, Dvorkin S, Endres M, Jedrzejczak R, Jones KA, Kang S, Kathayat RS, Kim Y and Lisnyak VG et al.. (2021) Structure of papain-like protease from SARS-CoV-2 and its complexes with non-covalent inhibitors. Nat Commun 12: 743 [PMID:33531496]

75. Outlaw VK, Bovier FT, Mears MC, Cajimat MN, Zhu Y, Lin MJ, Addetia A, Lieberman NAP, Peddu V and Xie X et al.. (2020) Inhibition of Coronavirus Entry In Vitro and Ex Vivo by a LipidConjugated Peptide Derived from the SARS-CoV-2 Spike Glycoprotein HRC Domain. mBio 11 [PMID:33082259]

76. Owen DR, Allerton CMN, Anderson AS, Aschenbrenner L, Avery M, Berritt S, Boras B, Cardin RD, Carlo A and Karen Coffman et al.. (2021) An Oral SARS-CoV-2 Mpro Inhibitor Clinical Candidate for the Treatment of COVID-19 medRxiv

77. Pathak N, Chen YT, Hsu YC, Hsu NY, Kuo CJ, Tsai HP, Kang JJ, Huang CH, Chang SY and Chang YH et al.. (2021) Uncovering Flexible Active Site Conformations of SARS-CoV-2 3CL Proteases through Protease Pharmacophore Clusters and COVID-19 Drug Repurposing. ACS Nano 15: 857-872 [PMID:33373194]

78. Pei P, Qin H, Chen J, Wang F, He C, He S, Hong B, Liu K, Qiao RZ and Fan H et al.. (2021) 
Computational design of ultrashort peptide inhibitors of the receptor-binding domain of the SARS-CoV-2 S protein. Brief Bioinform [PMID:34180984]

79. Peng Q, Peng R, Yuan B, Zhao J, Wang M, Wang X, Sun Y, Fan Z, Qi J and Gao GF et al.. (2020) Structural and biochemical characterization of nsp12-nsp7-nsp8 core polymerase complex from SARS-CoV-2 Cell Reports

80. Pervushin K, Tan E, Parthasarathy K, Lin X, Jiang FL, Yu D, Vararattanavech A, Soong TW, Liu DX and Torres J. (2009) Structure and inhibition of the SARS coronavirus envelope protein ion channel. PLoS Pathog 5: e1000511 [PMID:19593379]

81. Petersen E, Koopmans M, Go U, Hamer DH, Petrosillo N, Castelli F, Storgaard M, Al Khalili S and Simonsen L. (2020) Comparing SARS-CoV-2 with SARS-CoV and influenza pandemics. Lancet Infect Dis 20: e238-e244 [PMID:32628905]

82. Pfefferle S, Krähling V, Ditt V, Grywna K, Mühlberger E and Drosten C. (2009) Reverse genetic characterization of the natural genomic deletion in SARS-Coronavirus strain Frankfurt-1 open reading frame $7 \mathrm{~b}$ reveals an attenuating function of the $7 \mathrm{~b}$ protein in-vitro and in-vivo. Virol $\mathrm{J} \mathbf{6}$ : 131 [PMID:19698190]

83. Pillaiyar T, Manickam M, Namasivayam V, Hayashi Y and Jung SH. (2016) An Overview of Severe Acute Respiratory Syndrome-Coronavirus (SARS-CoV) 3CL Protease Inhibitors: Peptidomimetics and Small Molecule Chemotherapy. J Med Chem 59: 6595-628 [PMID:26878082]

84. PostEra AI. MPro Activity Data

85. Pruijssers AJ and Denison MR. (2019) Nucleoside analogues for the treatment of coronavirus infections. Curr Opin Virol 35: 57-62 [PMID:31125806]

86. Qiao J, Li YS, Zeng R, Liu FL, Luo RH, Huang C, Wang YF, Zhang J, Quan B and Shen C et al.. (2021) SARS-CoV-2 M $\mathrm{M}^{\text {pro }}$ inhibitors with antiviral activity in a transgenic mouse model. Science [PMID:33602867]

87. Rappazzo CG, Tse LV, Kaku CI, Wrapp D, Sakharkar M, Huang D, Deveau LM, Yockachonis TJ, Herbert AS and Battles MB et al.. (2021) Broad and potent activity against SARS-like viruses by an engineered human monoclonal antibody. Science 371: 823-829 [PMID:33495307]

88. Rathnayake AD, Zheng J, Kim Y, Perera KD, Mackin S, Meyerholz DK, Kashipathy MM, Battaile KP, Lovell S and Perlman S et al.. (2020) 3C-like protease inhibitors block coronavirus replication in vitro and improve survival in MERS-CoV-infected mice. Sci Transl Med 12 [PMID:32747425]

89. Ratia K, Pegan S, Takayama J, Sleeman K, Coughlin M, Baliji S, Chaudhuri R, Fu W, Prabhakar BS and Johnson ME et al.. (2008) A noncovalent class of papain-like protease/deubiquitinase inhibitors blocks SARS virus replication. Proc Natl Acad Sci USA 105: 16119-24 [PMID:18852458]

90. Riva L, Yuan S, Yin X, Martin-Sancho L, Matsunaga N, Pache L, Burgstaller-Muehlbacher S, De Jesus PD, Teriete P and Hull MV et al.. (2020) Discovery of SARS-CoV-2 antiviral drugs through large-scale compound repurposing Nature

91. Rosas-Lemus M, Minasov G, Shuvalova L, Inniss NL, Kiryukhina O, Brunzelle J and Satchell KJF. (2020) High-resolution structures of the SARS-CoV-2 2'-O-methyltransferase reveal strategies for structure-based inhibitor design Science Signaling 13: eabe1202

92. Ruch TR and Machamer CE. (2012) The coronavirus E protein: assembly and beyond. Viruses 4: 363-82 [PMID:22590676]

93. Saikatendu KS, Joseph JS, Subramanian V, Clayton T, Griffith M, Moy K, Velasquez J, Neuman BW, Buchmeier MJ and Stevens RC et al.. (2005) Structural basis of severe acute respiratory syndrome coronavirus ADP-ribose-1"-phosphate dephosphorylation by a conserved domain of nsP3. Structure 13: 1665-75 [PMID:16271890]

94. Schuller M, Correy GJ, Gahbauer S, Fearon D, Wu T, Diaz RE, Young ID, Martins LC, Smith DH and Schulze-Gahmen U et al.. (2021) Fragment binding to the Nsp3 macrodomain of SARS-CoV2 identified through crystallographic screening and computational docking Science Advances 7: eabf8711

95. Shahid M and Shahzad-Ul-Hussan S. (2020) Structural insights of key enzymes into therapeutic intervention against SARS-CoV-2. J Struct Biol 213: 107690 [PMID:33383190]

96. Shan H, Liu J, Shen J, Dai J, Xu G, Lu K, Han C, Wang Y, Xu X and Tong Y et al.. (2021) Development of potent and selective inhibitors targeting the papain-like protease of SARS-CoV2. Cell Chem Biol [PMID:33979649]

97. Shi CS, Qi HY, Boularan C, Huang NN, Abu-Asab M, Shelhamer JH and Kehrl JH. (2014) SARScoronavirus open reading frame-9b suppresses innate immunity by targeting mitochondria and the MAVS/TRAF3/TRAF6 signalosome. J Immunol 193: 3080-9 [PMID:25135833]

98. Shin D, Mukherjee R, Grewe D, Bojkova D, Baek K, Bhattacharya A, Schulz L, Widera M, Mehdipour AR and Tascher G et al.. (2020) Papain-like protease regulates SARS-CoV-2 viral spread and innate immunity. Nature 587: 657-662 [PMID:32726803]

99. Su YCF, Anderson DE, Young BE, Linster M, Zhu F, Jayakumar J, Zhuang Y, Kalimuddin S, Low JGH and Tan CW et al.. (2020) Discovery and Genomic Characterization of a 382-Nucleotide 
Deletion in ORF7b and ORF8 during the Early Evolution of SARS-CoV-2. mBio 11

[PMID:32694143]

100. Surya W, Li Y, Verdià-Bàguena C, Aguilella VM and Torres J. (2015) MERS coronavirus envelope protein has a single transmembrane domain that forms pentameric ion channels. Virus Res 201: 61-6 [PMID:25733052]

101. Tan YJ, Fielding BC, Goh PY, Shen S, Tan TH, Lim SG and Hong W. (2004) Overexpression of 7a, a protein specifically encoded by the severe acute respiratory syndrome coronavirus, induces apoptosis via a caspase-dependent pathway. J Virol 78: 14043-7 [PMID:15564512]

102. Tanner JA, Watt RM, Chai YB, Lu LY, Lin MC, Peiris JS, Poon LL, Kung HF and Huang JD. (2003) The severe acute respiratory syndrome (SARS) coronavirus NTPase/helicase belongs to a distinct class of 5' to 3' viral helicases. J Biol Chem 278: 39578-82 [PMID:12917423]

103. te Velthuis AJ, van den Worm SH and Snijder EJ. (2012) The SARS-coronavirus nsp7+nsp8 complex is a unique multimeric RNA polymerase capable of both de novo initiation and primer extension. Nucleic Acids Res 40: 1737-47 [PMID:22039154]

104. ter Meulen J, van den Brink EN, Poon LL, Marissen WE, Leung CS, Cox F, Cheung CY, Bakker AQ, Bogaards JA and van Deventer E et al.. (2006) Human monoclonal antibody combination against SARS coronavirus: synergy and coverage of escape mutants. PLoS Med 3: e237 [PMID:16796401]

105. Thanigaimalai P, Konno S, Yamamoto T, Koiwai Y, Taguchi A, Takayama K, Yakushiji F, Akaji K, Chen SE and Naser-Tavakolian A et al.. (2013) Development of potent dipeptide-type SARS-CoV 3CL protease inhibitors with novel P3 scaffolds: design, synthesis, biological evaluation, and docking studies. Eur J Med Chem 68: 372-84 [PMID:23994330]

106. Thanigaimalai P, Konno S, Yamamoto T, Koiwai Y, Taguchi A, Takayama K, Yakushiji F, Akaji K, Kiso Y and Kawasaki Y et al.. (2013) Design, synthesis, and biological evaluation of novel dipeptide-type SARS-CoV 3CL protease inhibitors: structure-activity relationship study. Eur J Med Chem 65: 436-47 [PMID:23747811]

107. Thoms M, Buschauer R, Ameismeier M, Koepke L, Denk T, Hirschenberger M, Kratzat H, Hayn M, Mackens-Kiani T and Cheng J et al.. (2020) Structural basis for translational shutdown and immune evasion by the Nsp1 protein of SARS-CoV-2. Science 369: 1249-1255 [PMID:32680882]

108. Tian X, Li C, Huang A, Xia S, Lu S, Shi Z, Lu L, Jiang S, Yang Z and Wu Y et al.. (2020) Potent binding of 2019 novel coronavirus spike protein by a SARS coronavirus-specific human monoclonal antibody. Emerg Microbes Infect 9: 382-385 [PMID:32065055]

109. Turlington M, Chun A, Tomar S, Eggler A, Grum-Tokars V, Jacobs J, Daniels JS, Dawson E, Saldanha A and Chase P et al.. (2013) Discovery of N-(benzo[1,2,3]triazol-1-yl)-N(benzyl)acetamido)phenyl) carboxamides as severe acute respiratory syndrome coronavirus (SARS-CoV) 3CLpro inhibitors: identification of ML300 and noncovalent nanomolar inhibitors with an induced-fit binding. Bioorg Med Chem Lett 23: 6172-7 [PMID:24080461]

110. Vankadara S, Wong YX, Liu B, See YY, Tan LH, Tan QW, Wang G, Karuna R, Guo X and Tan ST et al.. (2021) A head-to-head comparison of the inhibitory activities of 15 peptidomimetic SARSCoV-2 3CLpro inhibitors. Bioorg Med Chem Lett 48: 128263 [PMID:34271072]

111. Vasilenko N, Moshynskyy I and Zakhartchouk A. (2010) SARS coronavirus protein 7a interacts with human Ap4A-hydrolase. Virol J 7: 31 [PMID:20144233]

112. Vuong W, Khan MB, Fischer C, Arutyunova E, Lamer T, Shields J, Saffran HA, McKay RT, van Belkum MJ and Joyce MA et al.. (2020) Feline coronavirus drug inhibits the main protease of SARS-CoV-2 and blocks virus replication. Nat Commun 11: 4282 [PMID:32855413]

113. Walls AC, Park YJ, Tortorici MA, Wall A, McGuire AT and Veesler D. (2020) Structure, Function, and Antigenicity of the SARS-CoV-2 Spike Glycoprotein. Cell 181: 281-292.e6 [PMID:32155444]

114. Wang Q, Zhang Y, Wu L, Niu S, Song C, Zhang Z, Lu G, Qiao C, Hu Y and Yuen KY et al.. (2020) Structural and Functional Basis of SARS-CoV-2 Entry by Using Human ACE2. Cell 181: 894904.e9 [PMID:32275855]

115. Wang W, Zhou Z, Xiao X, Tian Z, Dong X, Wang C, Li L, Ren L, Lei X and Xiang Z et al.. (2021) SARS-CoV-2 nsp12 attenuates type I interferon production by inhibiting IRF3 nuclear translocation. Cell Mol Immunol [PMID:33637958]

116. Wang Y, Anirudhan V, Du R, Cui Q and Rong L. (2020) RNA-dependent RNA polymerase of SARS-CoV-2 as a therapeutic target. J Med Virol [PMID:32633831]

117. Westberg M, Su Y, Zou X, Ning L, Hurst B, Tarbet B and Lin MZ. (2021) Rational design of a new class of protease inhibitors for the potential treatment of coronavirus diseases bioRxiv

118. Wilson L, McKinlay C, Gage P and Ewart G. (2004) SARS coronavirus E protein forms cationselective ion channels. Virology 330: 322-31 [PMID:15527857]

119. Wiser C, Kim B and Ascano M. (2019) G3BP1 enhances cytoplasmic DNA pattern recognition. Nat Immunol 20: 5-7 [PMID:30538338]

120. Węglarz-Tomczak E, Tomczak JM, Talma M and Brul S. (2020) Ebselen as a highly active inhibitor of PLProCoV2 bioRxiv

121. Xia S, Liu M, Wang C, Xu W, Lan Q, Feng S, Qi F, Bao L, Du L and Liu S et al.. (2020) Inhibition of SARS-CoV-2 (previously 2019-nCoV) infection by a highly potent pan-coronavirus fusion inhibitor targeting its spike protein that harbors a high capacity to mediate membrane fusion. 
Cell Res 30: 343-355 [PMID:32231345]

122. Xia S, Yan L, Xu W, Agrawal AS, Algaissi A, Tseng CK, Wang Q, Du L, Tan W and Wilson IA et al.. (2019) A pan-coronavirus fusion inhibitor targeting the HR1 domain of human coronavirus spike. Sci Adv 5: eaav4580 [PMID:30989115]

123. Xia Z, Sacco M, Hu Y, Ma C, Meng X, Zhang F, Szeto T, Xiang Y, Chen Y and Wang J. (2021) Rational Design of Hybrid SARS-CoV-2 Main Protease Inhibitors Guided by the Superimposed Cocrystal Structures with the Peptidomimetic Inhibitors GC-376, Telaprevir, and Boceprevir. ACS Pharmacol Transl Sci 4: 1408-1421 [PMID:34414360]

124. Xiang Y, Nambulli S, Xiao Z, Liu H, Sang Z, Duprex WP, Schneidman-Duhovny D, Zhang C and Shi Y. (2020) Versatile and multivalent nanobodies efficiently neutralize SARS-CoV-2. Science 370: 1479-1484 [PMID:33154108]

125. Xu K, Zheng BJ, Zeng R, Lu W, Lin YP, Xue L, Li L, Yang LL, Xu C and Dai J et al.. (2009) Severe acute respiratory syndrome coronavirus accessory protein $9 \mathrm{~b}$ is a virion-associated protein. Virology 388: 279-85 [PMID:19394665]

126. Yan R, Zhang Y, Li Y, Xia L, Guo Y and Zhou Q. (2020) Structural basis for the recognition of SARS-CoV-2 by full-length human ACE2. Science 367: 1444-1448 [PMID:32132184]

127. Yang H, Xie W, Xue X, Yang K, Ma J, Liang W, Zhao Q, Zhou Z, Pei D and Ziebuhr J et al.. (2005) Design of wide-spectrum inhibitors targeting coronavirus main proteases. PLoS Biol 3: e324 [PMID:16128623]

128. Yang KS, Ma XR, Ma Y, Alugubelli YR, Scott DA, Vatansever EC, Drelich AK, Sankaran B, Geng ZZ and Blankenship LR et al.. (2020) A Speedy Route to Multiple Highly Potent SARS-CoV-2 Main Protease Inhibitors. bioRxiv [PMID:32766582]

129. Yang S, Chen SJ, Hsu MF, Wu JD, Tseng CT, Liu YF, Chen HC, Kuo CW, Wu CS and Chang LW et al.. (2006) Synthesis, crystal structure, structure-activity relationships, and antiviral activity of a potent SARS coronavirus 3CL protease inhibitor. J Med Chem 49: 4971-80 [PMID:16884309]

130. Yang W, Ru Y, Ren J, Bai J, Wei J, Fu S, Liu X, Li D and Zheng H. (2019) G3BP1 inhibits RNA virus replication by positively regulating RIG-I-mediated cellular antiviral response. Cell Death Dis 10: 946 [PMID:31827077]

131. Yoshimoto FK. (2020) The Proteins of Severe Acute Respiratory Syndrome Coronavirus-2 (SARS CoV-2 or n-COV19), the Cause of COVID-19 The Protein Journal volume 39: 198-216

132. Young BE, Fong S-W, Chan Y-H, Mak T-M, Ang LW and Anderson DE. (2020) Effects of a major deletion in the SARS-CoV-2 genome on the severity of infection and the inflammatory response: an observational cohort study The Lancet

133. Yuan M, Wu NC, Zhu X, Lee CD, So RTY, Lv H, Mok CKP and Wilson IA. (2020) A highly conserved cryptic epitope in the receptor binding domains of SARS-CoV-2 and SARS-CoV. Science 368: 630-633 [PMID:32245784]

134. Zaher NH, Mostafa MI and Altaher AY. (2020) Design, synthesis and molecular docking of novel triazole derivatives as potential CoV helicase inhibitors. Acta Pharm 70: 145-159 [PMID:31955138]

135. Zhang C-H, Spasov KA, Reilly RA, Hollander K, Stone EA, Ippolito JA, Liosi M-A, Deshmukh MG, Tirado-Rives J and Zhang S et al.. (2021) Optimization of Triarylpyridinone Inhibitors of the Main Protease of SARS-CoV-2 to Low-Nanomolar Antiviral Potency ACS Medicinal Chemistry Letters

136. Zhang C-H, Stone EA, Deshmukh M, Ippolito JA, Ghahremanpour MM, Tirado-Rives J, Spasov KA, Zhang S, Takeo Y and Kudalkar SN et al.. (2021) Potent Noncovalent Inhibitors of the Main Protease of SARS-CoV-2 from Molecular Sculpting of the Drug Perampanel Guided by Free Energy Perturbation Calculations ACS Central Science

137. Zhang L, Li L, Yan L, Ming Z, Jia Z, Lou Z and Rao Z. (2018) Structural and Biochemical Characterization of Endoribonuclease Nsp15 Encoded by Middle East Respiratory Syndrome Coronavirus. J Virol 92 [PMID:30135128]

138. Zhang L, Lin D, Kusov Y, Nian Y, Ma Q, Wang J, von Brunn A, Leyssen P, Lanko K and Neyts J et al.. (2020) $\alpha$-Ketoamides as Broad-Spectrum Inhibitors of Coronavirus and Enterovirus Replication: Structure-Based Design, Synthesis, and Activity Assessment. J Med Chem 63: 45624578 [PMID:32045235]

139. Zhang L, Lin D, Sun X, Curth U, Drosten C, Sauerhering L, Backer S, Rox K and Hilgenfeld R. (2020) Crystal structure of SARS-CoV-2 main protease provides a basis for design of improved $\alpha$-ketoamide inhibitors Science

140. Zhang L, Lin D, Sun X, Curth U, Drosten C, Sauerhering L, Becker S, Rox K and Hilgenfeld R. (2020) Crystal structure of SARS-CoV-2 main protease provides a basis for design of improved a-ketoamide inhibitors. Science 368: 409-412 [PMID:32198291]

141. Zhang R, Wang K, Lv W, Yu W, Xie S, Xu K, Schwarz W, Xiong S and Sun B. (2014) The ORF4a protein of human coronavirus $229 \mathrm{E}$ functions as a viroporin that regulates viral production. Biochim Biophys Acta 1838: 1088-95 [PMID:23906728]

142. Zhu W, Chen CZ, Gorshkov K, Xu M, Lo DC and Zheng W. (2020) RNA-Dependent RNA Polymerase as a Target for COVID-19 Drug Discovery. SLAS Discov 25: 1141-1151 [PMID:32660307] 
143. Zhu W, Xu M, Chen CZ, Guo H, Shen M, Hu X, Shinn P, Klumpp-Thomas C, Michael SG and Zheng W. (2020) Identification of SARS-CoV-2 3CL Protease Inhibitors by a Quantitative Highthroughput Screening. ACS Pharmacol Transl Sci

144. Zost SJ, Gilchuk P, Case JB, Binshtein E, Chen RE, Nkolola JP, Schäfer A, Reidy JX, Trivette A and Nargi RS et al.. (2020) Potently neutralizing and protective human antibodies against SARSCoV-2. Nature 584: 443-449 [PMID:32668443] 